\title{
Role of Advertising Expenditure as an Influential Non-traditional Regressor in Russia's Money Demand Specification
}

\author{
Lee-Chea Hiew ${ }^{1}$, Chin-Hong Puah $^{2}$, Mohammad Affendy Arip ${ }^{2} \&$ Mei-Teing Chong ${ }^{2}$ \\ ${ }^{1}$ Faculty of Hospitality and Tourism Management, UCSI University Sarawak Campus, Sarawak, Malaysia \\ ${ }^{2}$ Faculty of Economics and Business, Universiti Malaysia Sarawak, Sarawak, Malaysia \\ Correspondence: Chin-Hong Puah, Faculty of Economics and Business, Universiti Malaysia Sarawak, 94300 Kota \\ Samarahan, Sarawak, Malaysia. Tel: 60-8258-4294.
}

Received: July 14, 2019

Accepted: August 29, 2019

Online Published: September 8, 2019

doi:10.5430/ijfr.v10n6p232

URL: https://doi.org/10.5430/ijfr.v10n6p232

\begin{abstract}
The term advertising refers to the strategy that affects consumer behaviour and induces higher household final consumption expenditure (HFCE), which is associated with incredibly demanding for money upon transaction usages and a reduction in search costs. The model of money demand that is stable, reliable and well defined is crucial for central banks in formulating their monetary policy to minimise the gap between the supply and demand of money. Hence, this paper examines the influence of expenditure in advertising (ADEX) towards the level of demand for money among the households in Russia. An approach known as Autoregressive distributed lag (ARDL) is opted to model the money demand function (MDF) of Russia and nine years of quarterly data from 2008 to 2016 have been used in the estimation. Empirical findings reveal that ADEX not only positively influences the Russian's money demand in long term, its MDF also becomes more superior when the ADEX has been added. As such, this study suggests that ADEX can be taken into account as a non-traditional explanatory variable in the formulation of a stable and well-specified MDF for the case in Russia.
\end{abstract}

Keywords: money demand, advertising expenditure

\section{Introduction}

The economic dynamic for a country's development is formed with denoting to the practice of monetary policy, the level of demand and supply for money and the measure of monetary aggregates. During the financial reforms in the 1980s, the stability of money demand function (MDF) in most countries (including Russia) was compromised by bundles of money injected into the market due to financial market liberalisation and deregulation. Such changes in monetary policy indirectly affected market liquidity, consequently heightening international capital mobility. The monetary policy used by the Bank of Russia was framed on exchange rate from 1992 to 1998 (post-Soviet period) since there was considerable economic and financial vulnerability coupled with hyperinflation from 1992 to 1994 and high inflation from 1995 to 1998. Later in 1999, the inflation regime was used to replace credit policy as the operational procedure in assisting the monetary policy. In 2005, a dual-currency basket was introduced as the operational target in 2005 so as to iron out the instability of the rouble's exchange rate in relation to other major currencies. Following this, the global financial crisis forced the central bank of Russia Federation (CBR) to reform its monetary policy using inflation targeting in order to moderate the depreciation of the rouble. Today, the CBR still target their monetary policy framework with inflation-oriented.

Looking into inflation regime, Eichengreen (2006) listed three reasons that make inflation targeting difficult in emerging markets: (1) their liabilities are "dollarised" (the denomination of banking system deposits and lending in an identical currency), (2) they incur rather high pass-through effects and (3) their policymakers lack of credibility. The lack of credibility also implies that high interest rates are required to compensate for devaluation risk during the pegged exchange rate period. The lack of credibility is interrelated with extensive inflationary histories, which indicates the targeting framework based on inflation will not decrease the rates of interest to low inflation level. Also, the control of interest rates with exchange rate movements in inflation targeting can systematically indicate changes in consumer inflation dynamics ahead of their pass-through effects. Thus, Masson et al. (1998) stated that it is unlikely that the inflation targeting can perform well as a good monetary policy instrument in emerging markets. This statement is further supported by the studies of Fraga et al. (2004), and Daianu and Lungu (2007). The central 
bank is also encouraged to employ monetary targeting when the country's money demand is stable and predictable (Nachega, 2001; Mishkin, 2003; Kumar, 2007; Rao \& Kumar, 2009; and Khan \& Hye, 2013). As a result, the question of whether to carry on with inflation targeting or return to the manipulation of monetary targeting as the monetary policy strategy must be pondered if a stable MDF is to be found with the augmented of this non-traditional regressor, the advertising expenditure (ADEX).

In view of these circumstances, numerous researches have been studied to identify factors affecting the money demand in attempts to devise a stable, well-defined and predictable MDF. This information is crucial for central banks in formulating their monetary policy to reduce the difference between the level of money supply and demand. An oversupply of money will lead to inflation whereas the opposite may lead to market stagnation. In a continuing quest for a stable, well-defined and predictable MDF, some researchers have highlighted certain traditional regressors. However, the position of the non-traditional regressor - specifically, the ADEX in the MDF that Habibullah (2009) proposed has yet to become the focus. Throughout this paper, the term advertising refers to the strategy that affects consumer behaviour and induces higher household final consumption expenditure (HFCE), which is associated with a rising demand for money for transaction purposes and a reduction in search costs. Therefore, this study suggests to include ADEX into the MDF and then examines empirically its influence towards the demand for money for the case of Russia economy.

The contents in the paper are arranged into: Section 2, presents the development of advertising in economics and the ignorance of ADEX as an influential non-traditional regressor in the money demand specification. The next section discusses on the methodology and empirical framework of the study. Section 4, reveals the findings and discussions and Section 5, makes a concluding remark for the study.

\section{Literature Review}

Marshall $(1890,1919)$ was among the earliest researchers who explored the effect of advertising in economics. Although Marshall's concept was not officially integrated into economic theory, it contributed a crucial fundamental to the later expansion of conceptual frameworks in determining the role of advertising in the economy. Chamberlin (1933) then followed up this notion, which was later recognised as the first and foremost researcher to enlighten the importance of advertising in the monopolistic competition theory. In his discussion, demand elasticity for a product is improved when the "informative" feature of advertising is able to assist consumers in choosing a good that fulfils their needs and influences their reaction to different prices. This was later on supported by the studies of Ozga (1960) and Stigler (1961). The "persuasive" feature of advertising, on the other hand, influences consumer preferences and diminishes the demand elasticity of that particular product. Telser (1964) suggested that "advertising primarily affects demand by exerting a complementary influence in the consumer's utility function with the consumption of the advertised product". A later study by Stigler and Becker (1977) suggested that advertising acts as an alternative role (input) to sway consumption level towards the advertised products (output) and affects the utility function of consumers derived from various commodities' consumption. The process to transform from input to output requires an essential mechanism called the money demand transaction. Unlike the informative view, the complementary view is formulated to shape consumers' demand, which simultaneously involves the money demand even when no direct or indirect information is provided. In the modern economy, this circumstance is prominently affected by advertisements.

From the abovementioned theory development, it is important to note that the fundamental theories concerning advertising in economics have only focused on firms' sales/consumption levels and economic growth instead of looking at the actual money demand to consume or spend on the advertised goods/services. Although Telser (1964) contributed the complementary view that shapes consumer demand and simultaneously involves money demand, no further studies or expansion of theory has been carried out. In the past empirical studies for MDF, most researhers were focused on determinants other than ADEX, for example, exchange rate (Sahadudheen, 2012; Samimi et al., 2013; Bahmani-Oskooee et al., 2017; and Mahmood \& Alkhateeb, 2018), economic policy uncertainty (Bahmani-Oskooee et al., 2014), economic uncertainty (Lim \& Gan, 2015; and Kayongo \& Guloba, 2018), and financial innovation (Dunne \& Kasekende, 2018). Eventually, the research attention has gradually shifted to investigate the monetary model using divisia money. Studies contributed to the literature in this area include, but not limit to, Sianturi et al. (2017), Leong et al. (2018a, 2018b), Puah et al. (2018), Bahmani-Oskooee et al. (2019), Belongia and Ireland (2019), and Fuente et al. (2019). Attention was rather less in examining MDF using ADEX as a determinant. For this reason, Habibullah (2009) proposed the incorporation of ADEX as a non-traditional regressor for the MDF based on the extended consumer demand theory. Habibullah (2009) believed that ADEX has the ability to diminish households' search costs, consequently boosting the demand for money since consumption can be 
spawned through larger volume. However, literatures are rather less in considering ADEX in affecting the MDF and hence, the potential importance of this influential non-traditional regressor for MDF has lesser chance to be revealed.

\section{Data Descriptions and Methodology}

Quarterly data from the year of 2008 to 2016 were used since a longer span of data on Russia's advertising spending was hardly available. Note that only narrow money (i.e. M1 monetary aggregate) is employed as the regressand for Russia's MDF since it acts as an actual means of payment. The data used in this paper i.e. M1 (taken from Federal Reserve Bank of St. Louis), HFCE (sourced from Organisation for Economic Co-operation and Development Statistics), deposit rate (DR, provided by International Monetary Fund) and aggregate ADEX (obtained from Statista). Interpolation of data has been carried out for the HFCE and ADEX as only annually statistics are available for both of the data series. Subsequently, the MDF will be converted into real terms by assuming the price elasticity of nominal money balances equals to unity (see Neto \& Albuquerque, 2002; Bahmani-Oskooee \& Wang, 2007; Inoue \& Hamori, 2009; Rao \& Kumar, 2009; Albuquerque \& Gouvea, 2009; and Zhu et al., 2011). Specifically, the nominal terms in M1 monetary aggregate, HFCE and ADEX are adjusted to inflation using the consumer price index (CPI) in the base year of 2010. The CPI is collected from Census Economic and Information Center (CEIC) online database.

In general, the factors affecting money demand such as alternative investment opportunities can vary across sectors; therefore, selection of the scale variables or opportunity costs of holding money are different across countries (Seitz \& von Landesberger, 2010) due to the dissimilar structure of financial markets in every country (Rouhani et al., 2013). It simply means that the representable variables for the opportunity cost of carrying money are related to the country's financial market structure (Rouhani et al., 2013), including its policies implementation and, mainly, monetary policy.

Compared with other components of gross national product (GNP), consumption is more money intensive and it is the natural observable proxy for the unobservable permanent income if permanent income is an estimation or measurement for wealth, as argued by Mankiw and Summers (1986). The level of consumption also outperformed other proxies of the scale variable for the MDF (refer to Arestic et al., 1992; Arrau et al., 1995; and Howells \& Hussein, 1997). The constructiveness of consumption thus will be employed in line with the practice by Thomas (1993), Fujiki and Mulligan (1996), Tlelima and Turner (2004), Tang (2002, 2004, 2007), and Albuquerque and Gouvea (2009), to name few.

In addition, the own-rate of return measured by the domestic interest rate is always been used as the proxy of holding cash. As pointed out by Rouhani et al. (2013, p. 8), the interest rate's determination by policymakers and the fixing of the interest rate are of concern as well. Thus, we employed DR as the proxy of interest rate in the present study.

To determine the role of ADEX on Russian MDF, this study proposes two different money demand specifications. In Model 1, real HFCE (RHFCE) and deposit rate (DR) are defined as the determinants of real M1 (RM1). Then, real ADEX (RADEX) has been added into Model 1 to examine empirically the impact of RADEX on RM1 in Model 2. Equations (1) and (2) below show the empirical models of this paper.

\section{Model 1}

$$
\mathrm{LRM1}_{\mathrm{t}}=\alpha+\beta_{1} \mathrm{LRHFCE}_{\mathrm{t}}+\beta_{2} \mathrm{LDR}_{\mathrm{t}}+\mu_{\mathrm{t}}
$$

Model 2

$$
\mathrm{LRM}_{\mathrm{t}}=\alpha+\beta_{1} \text { LRHFCE }_{\mathrm{t}}+\beta_{2} \mathrm{LDR}_{\mathrm{t}}+\beta_{3} \text { LRADEX }_{\mathrm{t}}+\mu_{\mathrm{t}}
$$

where $\alpha$ is constant term, $\beta_{i}$ is the parameters/coefficients, and $\mu$ denotes an error term.

For equations (1) and (2) as shown below, the specification of MDF using the Autoregressive Distributed Lag (ARDL) can be written as:

\section{Model 1}

$$
\begin{aligned}
\Delta L R M 1_{t}= & \beta_{0}+\sum_{i=1}^{p} \alpha_{i} \Delta L R M 1_{t-i}+\sum_{i=0}^{p} \gamma_{i} \Delta L R H F C E_{t-i}+\sum_{i=0}^{p} \delta_{i} \Delta L D R_{t-i} \\
& +\theta_{1} L R M 1_{t-1}+\theta_{2} L R H F C E_{t-1}+\theta_{3} L D R_{t-1}+\omega_{t}
\end{aligned}
$$

Model 2

$$
\Delta L R M 1_{t}=\beta_{0}+\sum_{i=1}^{p} \alpha_{i} \Delta L R M 1_{t-i}+\sum_{i=0}^{p} \gamma_{i} \Delta L R H F C E_{t-i}+\sum_{i=0}^{p} \delta_{i} \Delta L D R_{t-i}+\sum_{i=0}^{p} \varphi_{i} \Delta L R A D E X_{t-i}
$$




$$
+\theta_{1} L R M 1_{t-1}+\theta_{2} L R H F C E_{t-1}+\theta_{3} L D R_{t-1}+\theta_{4} L R A D E X_{t-1}+\varepsilon_{t}
$$

where, $\Delta$ denotes the operator of first difference and $\varepsilon$ represents the noise term that assuming it is normally distributed and white noise; other notations are as depicted above.

Generally, economic reasoning suggests that $\beta_{1}$ and $\beta_{3}>0$ while $\beta_{2}<0$. Theory suggests that the scale variable is positively associated with the money demand and unitary income elasticity of demand. In addition, the scale variable itself can affect the presence of cointegrated relationship in the estimation of MDF (Ericsson, 1998). On the other hand, theory suggests there is a negative relationship between domestic interest rates and the level of money demand. A negative association between the holding of domestic currency and interest rates also implies that households will shift to hold other financial assets with higher return when the opportunity cost of holding domestic currency increases. Thus, it reduces the holding of domestic currency.

Moreover, this paper refers ADEX as the non-traditional regressor for money demand from either the producer or consumer standpoint (as illustrated in Figure 1). Consumers or households receive information about the business from advertisements broadcast by the mass media (as firms or investors invest in advertising), which then sparks their desire or "shopping" and "transaction" motives. With this, transaction demand money is needed to fulfil the desire or motives. Also, when investors make significant investments in advertising, the market size or sales of the business often improves and, as a consequence, demand for money increases too. The correlation between market performance and consumption has generally demonstrated that consumption increases due to an increase in sales or profit. Therefore, regardless of whether the demand for money is from the perspective of households (which represents the market demand) or investors (which represents the market supply), the ADEX is an "intermediate gadget" which drives the economy and/or business cycle.

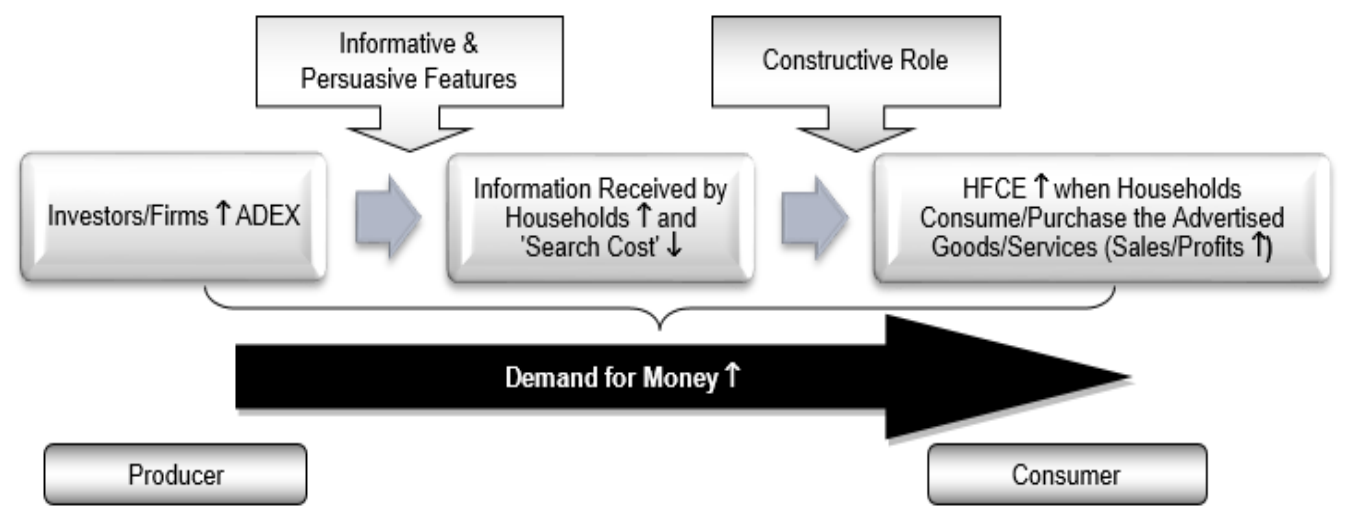

Figure 1. Process from ADEX to HFCE in increasing demand for money

Source: Authors' compilation.

\section{Empirical Findings and Discussions}

\subsection{ARDL Bounds Test}

Bounds test is utilized to detect the presence of cointgeration among the variables under study. In this sense, the F-statistic is tested to ascertain the presence of cointegrated relationship in Model 1 and Model 2. Table 1 shows that for both models, the computed F-statistic values are 8.259 and 11.291, respectively and both values exceed the critical values from the studies of Pesaran et al. (2001) and Narayan (2005) at 1\% level of significance. This implies that the variables in both empirical models exhibited a long-run cointegration relationship. 
Table 1. Results for the bounds test

\begin{tabular}{|c|c|c|c|c|c|c|c|c|}
\hline \multicolumn{5}{|l|}{ Models } & \multicolumn{4}{|c|}{$F$-statistic } \\
\hline \multicolumn{5}{|c|}{ Model 1: LRM1, LRHFCE and LDR } & \multicolumn{4}{|l|}{8.259} \\
\hline \multicolumn{5}{|c|}{ Model 2: LRM1, LRHFCE, LDR and LRADEX } & \multicolumn{4}{|l|}{11.291} \\
\hline \multicolumn{9}{|c|}{ Critical values bounds of the F-statistic: restricted intercept and no trend $(k=2$ and $k=3)$} \\
\hline \multirow[t]{3}{*}{ Significant Level } & \multicolumn{4}{|c|}{ Pesaran Critical Values } & \multicolumn{4}{|c|}{ Narayan Critical Values } \\
\hline & $k=2$ & & $k=3$ & & $k=2$ & & $k=3$ & \\
\hline & $I(0)$ & $I(1)$ & $I(0)$ & $I(1)$ & $I(0)$ & $I(1)$ & $I(0)$ & $I(1)$ \\
\hline $90 \%$ level & 2.63 & 3.35 & 2.37 & 3.20 & 4.800 & 5.725 & 4.270 & 5.142 \\
\hline $95 \%$ level & 3.10 & 3.87 & 2.79 & 3.67 & 3.368 & 4.203 & 3.078 & 4.022 \\
\hline $99 \%$ level & 4.13 & 5.00 & 3.65 & 4.66 & 2.788 & 3.540 & 2.560 & 3.428 \\
\hline
\end{tabular}

Note: The critical values used in the above are sourced from the tabulations on restricted intercept and no trend in Table Case II that appeared in both of the studies by Pesaran et al. (2001) and Narayan (2005).

Further inference is still considered since the presence of cointegration can be evidenced by the error correction term (ECT). The magnitude and significance of the ECT in each money demand equation demonstrate the aptitude of each short-run dynamic in adjusting to achieve equilibrium in long term. The ECT's coefficients (see Table 2, Panel A) for both money demand models carry the correct negative signs, less than unity and are statistically significant at the 1 percent level. Nevertheless, Kremers, Ericsson and Dolado (1992) argued that a significant ECT is a more powerful method to ascertain cointegration. This argument is supported by Banerjee and Newman (1993), and Bahmani-Oskooee and Brooks (1999) where they stated that a negative and significant ECT is comparably effective to indicate the presence of long term relationship among variables in the model. Later, this statement is also supported in the study of Kanioura and Turner (2005). This study therefore concludes that both models exhibit a stable relationship in long term. For these reasons, the inference that a significant MDF can be derived from both money demand models has been affirmed.

In comparing the speed of adjustment among the money demand models, one can see that the Model 2 (where ECT = -0.954 ) is slightly superior to the Model 1 (where ECT $=-0.269$ ). The speed of adjustment for the Model 2 is relatively faster than the Model 1. Specifically, the coefficient of ECT for Model 1 indicates that approximately 27 percent of adjustment happens in a quarter, implying that the model requires nearly a year to achieve equilibrium in long term. On the other hand, the lagged ECT for the Model 2 signifies that around 95.4 percent of short-run deviation is expected to be adjusted in each quarter to attain equilibrium in long term. Thus, about 1.05 quarters (less than one year) are needed to return disequilibrium to long-run stability. On the whole, Model 2 takes less time than the Model 1 for their short-run deviations to be adjusted to reach equilibrium in the long-run. Therefore, we should consider this non-traditional explanatory variable (ADEX) in the construction of MDF. The results of model diagnostic inspection are shown in Table 2, Panel B. Empirical findings report that both money demand models pass all the coefficient diagnostic tests. In addition, the stability tests further prove that the obtained parameters for both tested models are structurally stable over time. Therefore, it can be claimed that the obtained MDFs are well-specified and satisfactory as there is no significant problem of the ordinary least squares (OLS) estimation deficiency in both models.

Table 2. Error correction term and diagnostic tests results

\begin{tabular}{lllll}
\hline \multicolumn{2}{l}{ Model 1 (5, 1, 0) } & \multicolumn{2}{l}{ Model 2 (1, 1, 2, 1) } \\
\hline Panel A: Error Correction Term & & & Coefficient & t-statistic \\
\hline \multicolumn{1}{c}{ Coefficient } & t-statistic & & $-0.954 * * *$ & -8.092 \\
\hline $\mathrm{EC}_{\mathrm{t}-1}$ & $-0.269 * * *$ & -6.127 & $\mathrm{EC}_{\mathrm{t}-1}$ &
\end{tabular}




\begin{tabular}{llll}
\hline AR(2) & $1.801[0.406]$ & AR(2) & $0.401[0.818]$ \\
\hline RESET(1) & $3.761[0.066]^{*}$ & RESET(1) & $0.038[0.847]$ \\
\hline JB(2) & $1.862[0.394]$ & JB(2) & $3.346[0.188]$ \\
\hline ARCH(2) & $0.119[0.731]$ & ARCH(2) & $0.095[0.758]$ \\
\hline CUSUM & Stable & CUSUM & Stable \\
\hline CUSUMSQ & Stable & CUSUMSQ & Stable \\
\hline
\end{tabular}

Notes: Asterisks *,** and *** denote significant at the levels of $10 \%, 5 \%$ and $1 \%$, respectively. AR(2) is 2nd order Breusch-Godfrey serial correlation Lagrange Multiplier tests, RESET(1) denotes 1st order Ramsey's RESET test, $\mathrm{JB}(2)$ is Jarque-Bera 2nd order of normality test of the residuals, $\mathrm{ARCH}(2)$ represents 2nd order autoregressive conditional heteroskedasticity tests, CUSUM and CUSUM2Q are stability tests where the former tests on the cumulative sum of recursive residual whereas the latter tests on the cumulative sum of squares of recursive residual. Numbers in brackets [ ] indicate the p-values.

\subsection{Estimation of Long-Run Coefficients Using the ARDL Approach}

Table 3 displays the findings of the implied long-run MDF for Russia. A positive and significant estimation for RHFCE is obtained for both of the models. The obtained coefficient of 0.777 for Model 2 is rather close to unity as compared to 0.588 for Model 1 . Therefore, the result in Model 2 supports the notion of unitary income elasticity as proposed by the quantity theory of money. Additionally, the results suggest that the implied long-run elasticities for domestic interest rates (i.e. DR) in Model 1 and Model 2 are statistically significant at 10 and 1 percent levels, respectively with the correct negative signs, as suggested by a priori theory. This result also indicates that DR has negative relatioship with the money demand. During the opportunity cost of holding a domestic currency increases due to higher interest rates forgone, consumers will switch to alternative financial assets that offer higher returns.

Table 3. Long-run coefficient estimations

\begin{tabular}{llllll}
\hline Model 1 $(\mathbf{5 , 1 , 0 )}$ & & \multicolumn{5}{c}{ Model 2 $(\mathbf{1 , 1 , 2 , 1 )}$} \\
\hline Regressors & Coefficients & t-statistics & Regressors & Coefficients & t-statistics \\
\hline Constant & -4.520 & 1.597 & Constant & 1.612 & 3.294 \\
\hline LRHFCE & $0.588^{* *}$ & 2.432 & LRHFCE & $0.777^{* * *}$ & 14.983 \\
\hline LDR & $-0.168^{*}$ & -1.817 & LDR & $-0.132^{* * *}$ & -5.427 \\
\hline & & & LRADEX & $0.113^{* * *}$ & 3.294 \\
\hline
\end{tabular}

Note: Asterisks *, $* *$ and $* * *$ indicate significant at $10 \%, 5 \%$ and $1 \%$ levels, respectively.

Moreover, this study found that RADEX has a significant positive effect on M1. The parameter estimation with respect to RADEX is 0.113 for money demand in Model 2, indicating that expenditure on advertising influences the demand for money in Russia. Concisely, advertising plays a vital role in affecting consumers' behaviour in daily purchases, which may drive households to demand more domestic currency to acquire or consume the selected advertised products or services. This also means that the money demand will increase for consumption purposes through the transaction motive.

\subsection{Performance Evaluation}

To be a credible MDF, the model should pass all the common criteria. Specifically, the MDF must be cointegrated, stable over time and not suffer from any deficiency problems. Moreover, the coefficients in the estimation of cointegration must be consistent with a priori theory and statistically significant. Also, the MDF must have an acceptable adjustment speed towards equilibrium in long term. The criteria of evaluation in nominating the most appropriate MDFs are illustrated in Table 4. Although both models are cointegrated with satisfactory statistical properties, the long-run estimate of income elasticity in Model 2 is closer to unitary as suggested by quantity theory of money as compared to Model 1. In addition, in term of speed of adjustment from deviation to long-run equilibrium, Model 2 is faster than Model 1. These results imply that ADEX plays an essential role in generating a well-specified and stable MDF for the case of Russia. 
Table 4. Performance evaluation

\begin{tabular}{lll}
\hline & \multicolumn{2}{l}{ Money Demand Models } \\
\hline Criteria & Model 1 & Model 2 \\
\hline Coefficients in the estimations of long-run are consistent with a priori theory & Yes & Yes \\
\hline Cointegration (based on $\mathrm{ECT}_{\mathrm{t}-1}$ ) & Yes & Yes \\
\hline Speed of adjustment & Slower & Faster \\
\hline No deficiency problem & Yes & Yes \\
\hline Stability (CUSUM and CUSUMSQ) & Yes & Yes \\
\hline
\end{tabular}

\section{Conclusion}

In searching for a stable and well-defined MDF, researchers have utilised different explanatory variables in the past studies. Nevertheless, the use of ADEX, a non-traditional factor of the demand for money in the estimation of MDF has not been explored in the recent work until the first attempt by Habibullah (2009). In the present study, this study found supportive evidence on the inclusion of ADEX in formulating the MDF in Russia. Empirical findings indicate that ADEX can positively influence the level of money demand in long-run for the case of Russia. The estimation results become more superior when ADEX is added into the MDF. Thus, this finding lends credence to the importance of the non-traditional regressor (i.e. ADEX) in the formulation of a stable and well-specified MDF. This paper adds to the existing literatures on the MDF through empirically exploring the impact of ADEX on money demand. The variable of ADEX can be considered a non-traditional regressor in estimation of the MDF for future research. Moreover, this paper also suggests to consider monetary targeting as an alternative monetary policy since a stable and predictable MDF is found in the case of Russia. Nevertheless, the study found that the ADEX data have limited availability and even if do, rather short range of annual data are commonly reported and thus interpolation of data has been carried out. In short, this study suggests that further studies can be conducted on the assessment of the threshold effects of the ADEX variable on money demand. Such a study can enlighten the effects of ADEX towards money demand at different threshold levels.

\section{Acknowledgements}

Financial support from Universiti Malaysia Sarawak, Research Acculturation Collaborative Effort (RACE) Grant Scheme [RACE/e(4)/1103/2014(11)] and MoE MyBrain15 are gratefully acknowledged.

\section{References}

Albuquerque, P. H., \& Gouvea, S. (2009). Canaries and vultures: A quantitative history of monetary mismanagement in Brazil. Journal of International Money and Finance, 28(3), 479-495. https://doi.org/10.1016/j.jimonfin.2008.12.005

Arestic, P., Hadjimatheou, G., \& Zis, G. (1992). The impact of financial innovations on the demand for money in the UK and Canada. Applied Economics Letters, 2(2), 115-123. https://doi.org/10.1080/758536015

Arrau, P., de Gregorio, J., Reinhart, C. M., \& Wickham, P. (1995). The demand for money in developing countries: Assessing the role of financial innovation. Journal of Development Economics, 46(2), 317-340. https://doi.org/10.1016/0304-3878(94)00066-L

Bahmani-Oskooee, M., \& Brooks, T. J. A. (1999). Bilateral J-Curve between US and her trading partners. Review of World Economics, 135(1), 156-165. https://doi.org/10.1007/BF02708163

Bahmani-Oskooee, M., \& Wang, Y. Q. (2007). How stable is the demand for money in China? Journal of Economic Development, 32(1), 21-33. https://doi.org/10.35866/caujed.2007.32.1.002

Bahmani-Oskooee, M., Bahmani, S., Kones, A., \& Kutan, A. M. (2014). Policy uncertainty and the demand for money in the United Kingdom. Applied Economics, 47(11), 1151-1157. https://doi.org/10.1080/00036846.2014.993138

Bahmani-Oskooee, M., Bahmani, S., Kutan, A. M., \& Dan, X. (2019). On the asymmetric effects of exchange rate changes on the demand for money: Evidence from emerging economics. Journal of Emerging Market Finance, 18(1), 1-22. https://doi.org/10.1177/0972652719831523

Bahmani-Oskooee, M., Halicioglu, F., \& Bahmani, S. (2017). Do exchange rate changes have symmetric or 
asymmetric effects on the demand for money in Turkey? Applied Economics, 49(42), 4261-4270.

Banerjee, A., \& Newman, A. (1993). Occupational choice and the process of development. Journal of Political Economy, 101(2), 274-298. https://doi.org/10.1086/261876

Belongia, M. T., \& Ireland, P. N. (2019). The demand for divisia money: Theory and evidence. Journal of Macroeconomics, 61, 103-128. https://doi.org/10.1016/j.jmacro.2019.103128

Chamberlin, E. H. (1933). The theory of monopolistic competition. Cambridge, Mass: Harvard University Press.

Daianu, D., \& Lungu, L. (2007). Inflation targeting between rhetoric and reality. The case of transition economies. European Journal of Comparative Economics, 4(1), 39-64.

Dunne, J. P., \& Kasekende, E. (2018). Financial innovation and money demand: Evidence from Sub-Saharan Africa. South African Journal of Economics, 86(4), 1-21. https://doi.org/10.1111/saje.12205

Eichengreen, B. (2006). Can emerging markets float? Should they inflation target? In M. Vernengo (Ed.), Monetary integration and dollarization: No panacea. Cheltenham: Edward Elgar.

Ericsson, N. R. (1998). Empirical modeling of money demand. Empirical Economics, 23(3), 295-315.

Fraga, A., Goldfajn, I., \& Minella, A. (2004). Inflation targeting in emerging market economies. In NBER Macroeconomics Annual 2003 (Volume 18, pp. 365-416). National Bureau of Economic Research: MIT Press.

Fuente, G. D. L., Horra, L. P. D. L., \& Perote, J. (2019). The demand for Divisia money in the United States: evidence from the CFS Divisia M3 aggregate. Applied Economics Letters. https://doi.org/10.1080/13504851.2019.1606403

Fujiki, H., \& Mulligan, C. B. (1996). A structural analysis of money demand: Cross-sectional evidence from Japan (Bank of Japan Discussion Paper Series No. 96-E-7). Japan: Bank of Japan.

Habibullah, M. S. (2009) Money demand. Kuala Lumpur: Universiti Putra Malaysia, Press.

Howells, P., \& Hussein, K. (1997). The demand for money: Total transactions as the scale variable. Economics Letters, 55(3), 371-377. https://doi.org/10.1016/S0165-1765(97)00071-2

Inoue, T., \& Hamori, S. (2009). An empirical analysis of the money demand function in India. Economics Bulletin, 29(2), 1225-1246.

Kanioura, A., \& Turner, P. (2005). Critical values for an F-test for cointegration in a multivariate model. Applied Economics Letters, 37(3), 265-270. https://doi.org/10.1080/00036840412331315051

Kayongo, A., \& Guloba, A. (2019). Economic uncertainty and money demand stability in Uganda during financial liberalization: A GARCH and ARDL approach. Applied Economics and Finance, 5(4), 70-86.

Khan, R. E. A., \& Hye, Q. M. A. (2013). Financial liberalization and demand for money: A case of Pakistan. The Journal of Developing Areas, 47(2), 175-198. https://doi.org/10.1353/jda.2013.0034

Kremers, J. J. M., Ericsson, N. E., \& Dolado, J. J. (1992). The power of cointegration tests. Oxford Bulletin of Economics and Statistics, 54(3), 325-348. https://doi.org/10.1111/j.1468-0084.1992.tb00005.x

Kumar, S. (2007). The stability of demand for money in Bangladesh: Time series methods. The IUP Journal of Monetary Economics, 5(2), 27-35.

Leong, C. M., Puah, C. H., \& Ismail, S. (2018a). Divisia monetary model of exchange rate determination: The case of Philippines. Economic Annals-XXI, 172(7-8), 9-13.

Leong, C. M., Puah, C. H., \& Liew, V. K. S. (2018b). The impact of Divisia money on monetary model of exchange rate in Indonesia. Economics and Sociology, 11(2), 52-63. https://doi.org/10.14254/2071-789X.2018/11-2/4

Lim, S. Y., \& Gan, P. T. (2015). The demand for money and economic uncertainty. International Business Education Journal, 8(1), 15-21.

Mahmood, H., \& Alkhateeb, T. T. Y. (2018). Asymmetrical effects of real exchange rate on the money demand in Saudi Arabia: A non-linear ARDL approach. PLOS One, 13(11), 1-12.

Mankiw, N. G., \& Summers, L. H. (1986). Money demand and the effects of fiscal policies. Journal of Money, Credit, and Banking, 18(4), 415-429. https://doi.org/10.2307/1992462

Marshall, A. (1890). Principles of economics. London: MacMillan and Co.

Marshall, A. (1919). Industry and trade: A study of industrial technique and business organization; and of their 
influences on the conditions of various classes and nations. London: MacMillan and Co.

Masson, P. R., Savastano, M. A., \& Sharma, S. (1998). Can inflation targeting be a framework for monetary policy in developing countries? Journal of Finance and Development, 35(1), 34-37.

Mishkin, F. S. (2003). The economics of money, banking and financial markets (6th ed.). Boston: Addison-Wesley.

Nachega, J. C. (2001). A cointegration analysis of broad money demand in Cameron (IMF Working Paper WP/01/26). Washington, DC: International Monetary Fund. https://doi.org/10.5089/9781451844382.001

Narayan, P. K. (2005). The saving and investment nexus for China: Evidence from cointegration tests. Applied Economics, 37(17), 1979-1990. https://doi.org/10.1080/00036840500278103

Neto, F. A. F., \& Albuquerque, J. J. (2002). Indicadores derivados de agregados monetários. Brasília Working Papers Series No. 47. Brazil: Central Bank of Brazil.

Ozga, S. A. (1960). Imperfect markets through lack of knowledge. Quarterly Journal of Economics, 74(1), $29-52$.

Pesaran, M. H., Shin, Y., \& Smith, R. J. (2001). Bounds testing approaches to the analysis of level relationships. Journal of Applied Econometrics, 16(3), 289-326. https://doi.org/10.1002/jae.616

Puah, C. H., Leong, C. M., Abu Mansor, S., \& Lau, E. P. H. (2018). Revisiting money demand in Malaysia: simple-sum versus Divisia monetary aggregates. Jurnal Ekonomi Malaysia, 52(2), 267-278.

Rao, B. B., \& Kumar, S. (2009). A panel data approach to the demand for money and the effects of financial reforms in the Asian countries. Economic Modelling, 26(5), 1012-1017. https://doi.org/10.1016/j.econmod.2009.03.008

Rouhani, Z., Behname, M., \& Mostafavi, S. M. (2013). A comparative study for opportunity cost of holding money between selected developing and developed countries. Romanian Economic and Business Review, 8(4), 7-17.

Sahadudheen, I. (2012). Demand for money and exchange rate: Evidence for wealth effect in India. Undergraduate Economic Review, 8(1).

Samimi, A. J., Kenari, S. G., \& Ghajari, M. (2013). The impact of exchange rate on demand for money in Iran. International Journal of Business and Development Studies, 5(1), 39-60.

Seitz, F., \& von Landesberger, J. (2010). Household money holdings in the Euro area an explorative investigation. ECB Working Paper Series, No. 1238. Frankfurt, Germany: European Central Bank.

Sianturi, R., Tanjung, A., Leong, C. M., Puah, C. H., \& Brahmana, R. K. (2017). Financial Liberalization and Divisia Money Demand in Indonesia. Advanced Science Letters, 23(4), 3155-3158.

Stigler, G. J. (1961). The economics of information. Journal of Political Economy, 69(3), 213-225.

Stigler, G. J., \& Becker, G. S. (1977). De gustibus non est disputandum. American Economic Review, 67(2), 76-90.

Tang, T. C. (2002). Demand for M3 and expenditure components in Malaysia: Assessment from bound testing approach. Applied Economics Letters, 9(11), 721-725. https://doi.org/10.1080/13504850210126219

Tang, T. C. (2004). Demand for broad money and expenditure components in Japan: An empirical study. Japan and the World Economy, 16(4). 487-502. https://doi.org/10.1016/S0922-1425(03)00037-9

Tang, T. C. (2007). Money demand function for Southeast Asian countries: An empirical view from expenditure components. Journal of Economic Studies, 34(6), 476-496. https://doi.org/10.1108/01443580710830952

Telser, L. G. (1964). Advertising and competition. Journal of Political Economy, 72, 537-562.

Thomas, R. L. (1993). Introductory econometrics: Theory and applications (2nd ed.). New York: Longman Publishing.

Tlelima, T., \& Turner, P. (2004). The demand for money South Africa: Specification and tests for instability. South African Journal Economics, 72(1), 25-36. https://doi.org/10.1111/j.1813-6982.2004.tb00102.x

Zhu, M. N., Yu, H. Y., Chang, H. L., \& Su, C. W. (2011). Money demand function with asymmetric adjustment: Evidence on Brazil, Russia, India and China (BRICs). African Journal of Business Management, 5(14), 5449-5459. 